\title{
What Are the Research Focuses Regarding Learning in the Field of Operations Management in Higher Education? The Case of Spain in 2017
}

\author{
Juan A. Marin-Garcia (iD) \\ ${ }^{2}$ ROGLE Research Group, DOE Universitat Politècnica de València (Spain) \\ jamarin@omp.upv.es
}

Received:July 2018

Accepted: Sept 2018

\begin{abstract}
:
Purpose: What are the current research topics being studied by higher education professors in the area of operations management in Spain with regard to the learning of their students? Are the approaches that support these investigations adequate?

Design/methodology/approach: For the analysis, we have selected 25 publications in peer-reviewed scientific journals published by Spanish authors in 2017, and we have encoded them using Atlas.ti.

Findings: Most of the research centers on a very basic type of approach to learning, which reproduces the type of research typically conducted more than 40 years ago (type 1). For this reason, we propose an example of how to convert type 1 research questions into type 2 or 3 questions.

Originality/value: This paper collects and summarizes the main works on learning research carried out by members of ACEDEDOT and published in 2017, identifying themes, methods, levels of teacher conception and focus on the type of student learning. We intend to use this information to create a map of the current situation and propose possible suggestions to implement evidence-based instruction on operations management.
\end{abstract}

Keywords: Scholarship, student learning, student engagement, higher education.

\section{To cite this article:}

Marin-Garcia, J.A. (2018). What are the research focuses regarding learning in the field of operations management in higher education? The case of Spain in 2017. Journal of Industrial Engineering and Management, 11(4), 607-616. https://doi.org/10.3926/jiem.2550

\section{Introduction}

Instruction based on the evidence of what best promotes the learning of our students (Burke-Smalley, 2014; Cascio, 2007; Morrell \& Learmonth, 2015) is a trend in work and research that is gradually gaining ground, and is related to the foundation of the movement created under the label of scholarship (Boyer, 1990; Delbecq, 2007; Fernandez March, 2008; Mitchell \& Harvey, in press; Pearce, 2007).

This movement has had some, albeit weak, repercussion in the area of management (Ashkanasy, 2007; Delbecq, 2007; Gallos, 2008; New et al., 2008; Pearce, 2007) and accounting (Wilson, 2012). However, to date, there does not appear to be any relevant manifestation in the area of operations management.

We believe that the deep and scientific reflection on the way in which the operations management contents are learned is a pending topic in this discipline. For example, this shortcoming is clearly manifest in the review by 
Medina-López et al. (2011). This situation limits the impact or the efficiency of our work as scholars who not only conduct research, but primarily help transfer knowledge to students and professionals.

Furthermore, there has been a clear evolution in the meaning and implications of the levels of teaching conceptions and approaches to teaching (Gow \& Kember, 1993; Kember, 1997; Kember \& Gow, 1994; Prosser \& Trigwell, 1997) and of the approaches to learning by students (superficial, strategic and in-depth) (Biggs \& Tang, 2011 (1st edition 1999); Marton et al., 2005; Paricio Royo, 2013; Paricio Royo \& Allueva Pinilla, 2011; Ramsden, 1992; Trigwell et al., 1999). All these classic developments in teaching have marked the methodology and focus of the research on learning at the end of the last century and the early part of this one.

However, this begs the question: Are operations management instructors taking advantage of these developments? What have we as university professors in the area been investigating over the last year? Are the approaches appropriate that support our research?

This research aims to collect and summarize the main works about research on learning in operations management conducted in Spain in 2017. This will be used to identify topics, methods, types of teaching approaches and focus on type of student learning. This will allow us to create a map of the current situation in this country, show a working protocol for other researchers to analyze broader periods of time or to cover other countries, and make possible suggestions for building an evidence-based teaching of operations management.

\section{Objectives}

To identify research focuses on learning from the studies published in peer-reviewed scientific journals by professors of operations management who teach university courses in Spain (as part of a degree or master's program).

To reflect on how to improve research on learning in this area of corporate organization and its possible generalization to other academic fields.

\section{Context}

In this research, we will work with two dimensions that will enable us to identify the research focuses (Table 1).

On the one hand, we will focus on the type of research questions and we will analyze the type of teaching approach that supports them (Kember, 1997; Prosser \& Trigwell, 1997; Trigwell et al., 1999). We will characterize type 1 as those research questions that attempt to identify the best method/resource to achieve student learning. Type 2 is focused on how the students learn, what the students do or what leads them to choose one learning approach over another. Type 3 focuses its questions on identifying, in specific contexts, what good learning consists of and what students are learning during the course.

On the other hand, given that one of the variables that best explains the variability of the students' results or behaviors are the learning approaches that the student demonstrates (Marton et al., 2005), we will analyze which ones are present, explicitly or implicitly, in the published research.

Learning approaches that students choose can be classified into three types (Coffey \& Gibbs, 2002; Gibbs \& Coffey, 2000; Marton et al., 2005; Paricio Royo, 2013; Paricio Royo \& Allueva Pinilla, 2011; Ramsden, 1992): superficial (routinely storing unconnected information), strategic (doing homework or displaying behaviors that are rated favorably by the teacher, for the maximum possible grade, with the minimum effort required) and deep (engaging passionately in the learning by providing meaning to the concepts of the subject and linking them to personal development).

The categories of learning approaches have a direct relationship to the categories into which the learning conceptions, teaching conceptions or learning outcomes can be grouped. For example, the strategic approach will often require the student, in almost all undergraduate courses, to show some abilities or to be able to apply knowledge in a known context (exam-type questions or exercises similar to those done in class) or match what is shown in grading rubrics, but they normally do not go beyond presenting coherent responses with only limited arguments, since they have not invested time in trying to understand them in depth.

In principle, the research under any of the types of teaching approaches may be related to any of the learning approaches. Therefore, for example, a type 3 investigation can give rise to identifying the outcomes of student 
learning and whether they merely reproduce information (superficial) or are able to understand it (deep). Similarly, a type 1 investigation can consider which is the best method for achieving in-depth learning by students.

In educational research, much progress has been made in general areas, but little has been accomplished with regard to specific aspects. That is to say, we have come a long way in terms of type 1 and 2 teaching approaches, but further research is needed on matters related to type 3. We must try to find out the external and internal factors that condition the learning of a subject in a particular context. To do this, the work of teachers investigating from their specific didactic fields is crucial (Fernandez March, 2008; Fernández March, 2010).

\begin{tabular}{|c|c|c|c|c|}
\hline Research Focus & $\begin{array}{l}\text { Approaches } \\
\text { to learning }\end{array}$ & $\begin{array}{l}\text { Conception of } \\
\text { learning }\end{array}$ & $\begin{array}{l}\text { Conception of } \\
\text { teaching }\end{array}$ & $\begin{array}{l}\text { Learning } \\
\text { outcomes }\end{array}$ \\
\hline $\begin{array}{l}\text { Type } 1 \\
\text { How do I teach? } \\
\text { Focused on teaching. } \\
\text { What is the best } \\
\text { method for...? }\end{array}$ & Superficial & $\begin{array}{l}\text { Storing information or } \\
\text { expanding knowledge } \\
\text { on a routine basis }\end{array}$ & $\begin{array}{l}\text { Conveying } \\
\text { information/ } \\
\text { Transmitting } \\
\text { knowledge }\end{array}$ & $\begin{array}{l}\text { Incoherent lists of } \\
\text { information. } \\
\text { Reproduced brief } \\
\text { descriptions }\end{array}$ \\
\hline $\begin{array}{l}\text { Type } 2 \\
\text { How do they learn? } \\
\text { Student-focused. What } \\
\text { do students do or } \\
\text { what leads them to } \\
\text { choose one learning } \\
\text { approach over } \\
\text { another? }\end{array}$ & Strategic & $\begin{array}{l}\text { Applying knowledge } \\
\text { and skills }\end{array}$ & $\begin{array}{l}\text { Directing active } \\
\text { learning }\end{array}$ & $\begin{array}{l}\text { Outline of coherent } \\
\text { responses without } \\
\text { support }\end{array}$ \\
\hline $\begin{array}{l}\text { Type } 3 \\
\text { What do they learn? } \\
\text { Student-focused. What } \\
\text { does it mean to } \\
\text { learn/understand in } \\
\text { the context of my } \\
\text { course and how can I } \\
\text { measure it? }\end{array}$ & Deep & $\begin{array}{l}\text { Giving meaning to } \\
\text { ideas and personal } \\
\text { development }\end{array}$ & $\begin{array}{l}\text { Facilitating deep } \\
\text { understanding and } \\
\text { enhancing } \\
\text { conceptual change }\end{array}$ & $\begin{array}{l}\text { Complete, } \\
\text { substantiated } \\
\text { explanations. } \\
\text { Individual } \\
\text { conceptions on the } \\
\text { subject. Thinking } \\
\text { like professionals } \\
\text { think }\end{array}$ \\
\hline
\end{tabular}

Table 1. Dimensions of analysis for research focuses. (Adapted from Entwistle, 2000; Kember, 1997; Paricio Royo, 2017;

Paricio Royo \& Allueva Pinilla, 2011)

\section{Methodology}

We have only selected publications in peer-reviewed scientific journals for analysis. Works at conferences tend to suffer from incomplete methodological designs and show preliminary approaches which, if interesting, can be enriched in light of the opinions received at the conference to convert them into journal submissions. We believe that the works that have completed their academic journey in the conference phase and that have not been submitted to journals are incomplete or inconsequential works or works with low potential. Thus, their authors decide not to dedicate the effort needed to raise them up to a high-level academic discussion (such as that which may be fostered in the revision process and subsequent publication in scientific journals).

On the other hand, we believed that the course contents could be an important context variable (Entwistle \& Ramsden, 2015). This is not only because of the differences that might appear in relation to the specific learning and/or teaching processes (for example, it might not be the same to teach physics or business management or structural calculation or psychology or literature), but also according to the cultural context that surrounds a group of teachers related to a specific academic discipline. The teachers of certain subjects may share the same basic qualifications or common research methods or the problems that get their attention or modes of interpreting reality. Therefore, in selecting publications, we will focus only on the context of Spanish universities and on one academic discipline (operations management). 
The academic discipline of operations management in Spain falls within the scientific field of business sciences. The subjects in this discipline are usually present only in the degree or master's programs on business administration and in some of the engineering programs in the industrial branch (especially in the industrial engineering degree or in the industrial engineering master's degree). Perhaps for this reason, university professors of a course on operations management often have basic training in business administration or engineering. In Spain, there are two scientific associations to which university professors of operations management usually belong. On the one hand, there is ACEDEDOT, which is the operations and technology section of the Scientific Association of Economics and Business Administration (ACEDE). On the other hand, there is the association for the development of organizational engineering (ADINGOR). Although some professors belong to both associations, in general, we can state that ACEDEDOT is dominated by teachers with a more business administration profile, who are more closely linked to social sciences (although there are also engineers or people from the operational research area); while there is more of a presence of engineers in ADINGOR.

For this work, we will select articles related to university learning, published in 2017 by professors belonging to ACEDEDOT or ADINGOR. In addition, they must meet the criteria listed in Table 2.

After an initial literature search in which we identified 20 works, we contacted the professors of both associations either by email or in person, requesting them to send us the papers published on research in learning. As a result, we obtained 5 new works that form part of the total of 25 works that we will analyze.

Each of the selected works has been encoded, extracting the following information:

- Academic area of each of the authors: marked as "operations management" or "other" on the basis of the author's main publications, indexed in Scopus and Web of Science or Google Scholar, in the last 3 years (2014-2017)

- Research questions addressed in the article: the questions or contribution are explicitly established in the work

- For each contribution or research question:

- Type of approach to instruction: type 1, type 2, type 3, undefined

- Approaches to learning: superficial, strategic, deep, undefined

- Context information:

- Academic level of the contribution: 1st/2nd year of the degree, 3rd/4th year of the degree, master's, undefined

- Course subject to the study: if research focused on a specific course

- Average group size (students enrolled per group): small (less than 20 students), medium (more than 20 and less than 60), large (more than 60 students), undefined

- The name of the qualification of which the subject(s) are taught

- University

The process of encoding and analysis has been carried out with the help of the Atlas.ti program (Claver-Cortés et al., 2018; Marin-Garcia, 2007; Morente \& Ferràs, 2017).

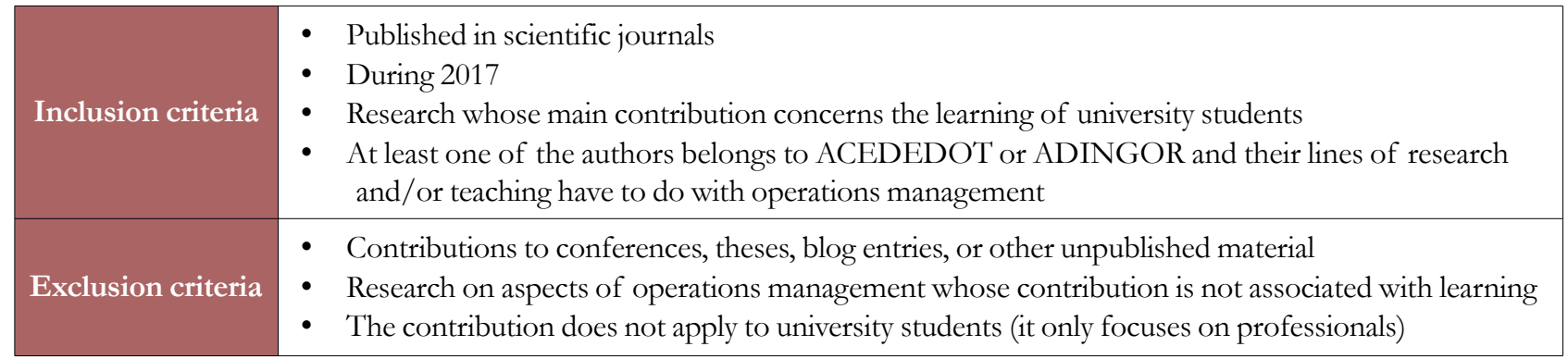

Table 2. Inclusion and exclusion criteria 


\section{Results}

In the 25 works analyzed, we found abundant disinformation to contextualize the experiences. Some works (between 4 and 6, depending on the variable to consider) have a generic approach and are not restricted to a specific context (university, degree, course, year of study or group size), because their contribution, in principle, is proposed as generalizable to any of these contexts. However, the rest of the works make reference to a specific experience. Seven of them explicitly state that they are contextualized in the business administration degree program, two others refer to electronic engineering, one to aerospace engineering and the other three including information about the degree are postgraduate studies (a master's degree in economics, another in business management and a university specialization in lean production). With regard to the courses, 7 are in operations management, 1 is on the supply chain, another is on lean production, another is on process improvement, two are on end-of-degree or master's projects and the other two are related to business organization. Given the selection criteria, it is not surprising that qualifications abound that are related to business administration, and that most of those contributing information are focused on subjects related to operations management. There is not much information about group size, but when it is provided, research on learning is usually conducted on courses with small groups (less than 20 students).

The research questions addressed by the works analyzed focus mainly on Type 1 approaches to conceptualization. 28 of the 33 research questions identified focus on what the professor does, and seek to justify the "best way to achieve something", either the best methodology for achieving a learning outcome by the students or the best method to assess what students have acquired ( $\mathrm{N}$ is greater than 25 because some works have several questions/contributions, each of them in the same or different type of teaching or learning approach). Only in 5 cases have we detected signs that the contribution focuses on the student, either on how they learn or what it would be appropriate for them to learn in the course.

In Table 3 we can observe how most of the works have a Type 1 of research focus and, at the same time, they analyze a superficial learning approach. However, 4 of the works with Type 1 seek to reflect on the deep learning of students and three others on aspects that could be associated with strategic learning. Apart from that, there were 9 research questions that we could not associate with any particular learning approach, due to a lack of information.

By way of example, we present in Table 4 how a Type 1 research question could be transformed into a battery of questions that would place the focus of research on a Type 2 or Type 3 conceptualization of teaching.

\begin{tabular}{|c|c|c|c|c|c|c|c|}
\hline ID & Type 1 & Type 2 & Type 3 & SAL-super & SAL-strat & SAL-deep & $\begin{array}{l}\text { SAL- } \\
\text { undef }\end{array}$ \\
\hline (Alfalla-Luque et al., 2017) & & 1 & & & & & 1 \\
\hline (Alhely et al., 2017) & & & & & & & 1 \\
\hline (Álvarez-Gil et al., 2017) & 2 & & & 2 & & & \\
\hline $\begin{array}{l}\text { (Andreu-Andrés et al., } \\
\text { 2017) }\end{array}$ & 1 & & & & & & 1 \\
\hline (Avella Camarero, 2017) & & & 1 & 1 & & 2 & \\
\hline $\begin{array}{l}\text { (Blanco \& Sanchez-Ruiz, } \\
\text { 2017) }\end{array}$ & 1 & & & & & & 1 \\
\hline (Canós-Darós et al., 2017) & & & & & & & 1 \\
\hline $\begin{array}{l}\text { (De Burgos Jiménez et al., } \\
\text { 2017) }\end{array}$ & 1 & & & 1 & 1 & & \\
\hline (Díaz Garrido et al., 2017) & 1 & & & 1 & & & \\
\hline $\begin{array}{l}\text { (Fernández-Zamora \& } \\
\text { Arias-Aranda, 2017) }\end{array}$ & 3 & 2 & & 2 & & 3 & 1 \\
\hline (Fossas-Olalla et al., 2017) & 1 & & & 1 & 2 & & \\
\hline $\begin{array}{l}\text { (García-Ramos \& } \\
\text { Martínez-Campillo, 2017) }\end{array}$ & 1 & & & & & 1 & \\
\hline (Guitart-Tarrés et al., 2017) & 1 & & & & & & 1 \\
\hline $\begin{array}{l}\text { (López-Sánchez et al., } \\
\text { 2017) }\end{array}$ & 1 & & & 2 & & & \\
\hline
\end{tabular}




\begin{tabular}{|c|c|c|c|c|c|c|c|}
\hline ID & Type 1 & Type 2 & Type 3 & SAL-super & SAL-strat & SAL-deep & $\begin{array}{l}\text { SAL- } \\
\text { undef }\end{array}$ \\
\hline $\begin{array}{l}\text { (Lopez Vargas \& Real, } \\
2017)\end{array}$ & 1 & & & & & & 1 \\
\hline $\begin{array}{l}\text { (Maqueira Marín et al., } \\
2017 \text { ) }\end{array}$ & 1 & & & & & & 1 \\
\hline $\begin{array}{l}\text { (Marimon \& Berbegal- } \\
\text { Mirabent, 2017) }\end{array}$ & 1 & & & 1 & & & \\
\hline (Marin-Garcia et al., 2017) & 2 & & & 2 & 2 & 2 & \\
\hline $\begin{array}{l}\text { Martínez Jurado \& } \\
\text { Moyano Fuentes, 2017) }\end{array}$ & 1 & & & & & & 1 \\
\hline (Oltra Mestre et al., 2017) & 1 & & & & & 1 & \\
\hline $\begin{array}{l}\text { Ramírez \& García- } \\
\text { Villaverde, 2017) }\end{array}$ & 1 & & & 1 & & 1 & \\
\hline (Rosillo et al., 2017) & 2 & & & 1 & & & \\
\hline (Sanchez-Ruiz et al., 2017) & 1 & & & & & & 1 \\
\hline (Vidal et al., 2017) & 2 & & & 1 & & & \\
\hline (Vidal-Carreras et al., 2017) & 1 & 1 & & 2 & & 1 & \\
\hline Total & 27 & 4 & 1 & 18 & 5 & 11 & 11 \\
\hline
\end{tabular}

Table 3. Works and number of questions/contributions by teaching and learning approaches

\section{Instead of... (type 1) $\quad \ldots$ Express it in this manner (type 2 and type 3 )}

Is gamification a good teaching tool? or does gamification help students to learn more?

What happens with students of the course XXXX in the 2017/2018 academic year when faced with gamified activity (or set of activities) YYYY? Do they become more stressed or are they more motivated? Is it only extrinsic motivation that is generated or does that motivation cause them to invest more hours and, in addition, increase intrinsic motivation? Are they aimed only at the outcomes highlighted in the gamification panel, or do they develop a deep learning with high intensity in relation to the course objectives and, in addition, extend their personal goals? What type of learning objectives/outcomes help build this gamification experience?

Table 4. Example of a proposal for the reformulation of research questions to go from a type 1 to a type 2 and type 3

approach

\section{Conclusions}

After the analysis carried out, it seems that the majority of the research is limited to a very basic approach that reproduces the usual type of investigations prior to 1980. This type of questions are considered obsolete, because they aspire to find a "silver bullet" that works successfully in any context and for any student. That is to say, if we teachers choose the correct method or activity, our students will achieve the expected learning results. It is as if the problem consisted of identifying the button or lever that activates the learning process in all of our students that leads to aligning them with the objectives that we propose, and devoting the effort required to achieve them.

However, the results of the last 30-40 years of research on learning seem to suggest that the mechanisms that guide the learning processes of the people enrolled in our courses are too complex and are the result of the interaction of too many variables to be able to conform to models as simple as those that support type 1 investigations. Therefore, the research that may be useful at this time is that representing type 2, or even better, type 3 .

As limitations to this work, we have only analyzed the publications from the last year (2017) and from a subset of Spanish university professors in the area. It would be desirable in future research to expand to publications in recent years. For example, it could extend back to 2012, to incorporate the new contributions following Medina-Lopez et al. (2011). Furthermore, the identification of articles has been carried out on the basis of the responses from potential authors. This procedure may have resulted in false negatives due to the lack of response or an oversight by the authors. Future research could use the updated review by Medina-Lopez et al. (2011), restricting it to the most recent years and Spanish authors. 
We understand that the reflections arising from the results cannot be generalized to all of the learning research conducted by Spanish university professors without performing similar studies in other areas of knowledge.

\section{Declaration of Conflicting Interests}

The author declared no potential conflicts of interest with respect to the research, authorship, and/or publication of this article. Preliminary versions of this research were presented in the following conferences: Marin-Garcia, Juan A. (2018). Focos de investigación sobre aprendizaje universitario en el área de dirección de operaciones. Congreso InRed 2018. UPV, 19-20 July 2018 (Valencia-Spain); and Marin-Garcia, Juan A. (2018). ¿Qué se investiga sobre aprendizaje de DO en España? IX Workshop in Operations Management and Technology. CUD-Universidad de Zaragoza 12-13 April 2018 (Zaragoza-Spain).

\section{Funding}

The author received no financial support for the research, authorship, and/or publication of this article.

\section{References}

Alfalla-Luque, R., Garrido-Vega, P., Del Mar González-Zamora, M., Medina-López, C., \& Sacristán-Díaz, M. (2017). Un análisis sobre las causas de abandono de los trabajos fin de máster an analysis of the causes of master's thesis dropouts. Working Papers on Operations Management, 8, 32-49. https://doi.org/10.4995/wpom.v8i0.7114

Alhely, B., Chávez, C., \& Miguel-Dávila, J.-Á. (2017). Experiencia docente de aplicación de kaizen en una empresa teaching experience of application of kaizen in a company. Working Papers on Operations Management, 8, 58-61.

Álvarez-Gil, M. J., Montes-Sancho, M. J., \& Tachizawa, E. M. (2017). A first approximation to the spocs-fc in the context of the supply chain management. WPOM-Working Papers on Operations Management, 8, 151-163. https://doi.org/10.4995/wpom.v8i0.7198

Andreu-Andrés, M. A., Marín-García, J. A., \& García-Carbonell, A. (2017). El barómetro incode como herramienta de autoevaluación de las competencias de innovación the barometer incode as a self-assessment tool of innovation competencies. REDU Revista de Educación Universitaria, 15(152), 275-294.

Ashkanasy, N. (2007). Critiques of management education and scholarship and suggestions for change. Academy of Management Learning \& Education, 6(1), 102. https://doi.org/10.5465/amle.2007.24401706

Avella Camarero, L. (2017). Estrechando los lazos universidad-empresas: Puesta en marcha del programa especialista en do y lean 6 sigma en respuesta a la demanda formativa de la industria. Working Papers on Operations Management, 8, 54-57.

Biggs, J., \& Tang, C. (2011) 0. Teaching for quality learning at university (1st Ed. 1999). New York: McGraw-Hill Education, SRHE and Open University Press.

Blanco, B., \& Sanchez-Ruiz, L. (2017). Fomentar el contacto con el mundo empresarial a través del trabajo fin de grado: Una experiencia aplicada a la temática de subcontratación encouraging contact with the business world through the final year project: An experience applied to the outsourcing field. Working Papers on Operations Management, 8, 62-66. https://doi.org/10.4995/wpom.v8i0.7159

Boyer, E. L. (1990). Scholarship reconsidered. Priorities of the professoriate. Princeton, NJ: Carnegie Foundation for the Advancement of Teaching.

Burke-Smalley, L. A. (2014). Evidence-based management education. Journal of Management Education, 38(5), $764-$ 767. https://doi.org/10.1177/1052562914529418

Canós-Darós, L., Morera, C. P., Santandreu Mascarell, C., Pilar, Y., \& Vidal-Carreras, I. (2017). La evaluación de la enseñanza: Algunas reflexiones evaluation of teaching: Some reflections. Working Papers on Operations Management, 8, 67-71. https://doi.org/10.4995/wpom.v8i0.7163

Cascio, W. F. (2007). Evidence-based management and the marketplace for ideas. Academy of Management Journal, 50(5), 1009-1012. https://doi.org/10.5465/amj.2007.27151942

Claver-Cortés, E., Zaragoza-Sáez, P., \& González Illescas, M. (2018). Intellectual capital management: An approach to organizational practices in ecuador. Intangible Capital, 14(2), 270-285.https://doi.org/10.3926/ic.1158 
Coffey, M., \& Gibbs, G. (2002). Measuring teachers' repertoire of teaching methods. Assessment and Evaluation in Higher Education, 27(4), 383-390. https:/ / doi.org/10.1080/0260293022000001382

De Burgos Jiménez, J., Felipe, J., Guerrero, J., \& Tarifa Fernández, J. (2017). Creación de materiales didácticos para trabajos fin de estudios en gestión de la cadena de suministro creation of didactic materials for dissertation in supply chain management. Working Papers on Operations Management, 8, 19-26. https://doi.org/10.4995/wpom.v8i0.7107

Delbecq, A. L. (2007). Scholarship and teaching that matters: Juxtaposing inner freedom with street-smart credibility. Journal of Management Education, 31, 376-391. https://doi.org/10.1177/1052562906298441

Díaz Garrido, E., Martín-Peña, M. L., \& Sánchez-López, J. M. (2017). The impact of flipped classroom on the motivation and learning of students in operations management. WPOM-Working Papers on Operations Management, 8 , 15-18. https://doi.org/10.4995/wpom.v8i0.7091

Entwistle, N. (2000). Promoting deep learning through teaching and assessment. In L. Suskie (Ed.., Assessment to promote deep learning: Insight from aahe's 2000 and 1999 assessment conferences (pp. 78). Washington: American Association for Higher Education.

Entwistle, N., \& Ramsden, P. (2015). Understanding student learning (routledge revivals): Routledge (1st Ed. 1983).

Fernández-Zamora, J. C., \& Arias-Aranda, D. (2017). Implementation of a gamification platform in a master degree (master in economics). WPOM-Working Papers on Operations Management, 8, 181-190.

https://doi.org/10.4995/wpom.v8i0.7431

Fernandez March, A. (2008). Training teachers in higher education. Teoría de la Educación, 20, 275-312.

Fernández March, A. (2010). La evaluación orientada al aprendizaje en un modelo de formación por competencias en la educación universitaria. Revista de Docencia Universitaria, 8(1), 11-34.

https://doi.org/10.4995/redu.2010.6216

Fossas-Olalla, M., Minguela-Rata, B., Fernández-Menéndez, J., \& Giménez-Fernández, E. (2017). Experiencia de aprendizaje mediante el uso de una app en los estudios de grado learning experience using an app in bachelor degree. Working Papers on Operations Management, 8, 92-100. https://doi.org/10.4995/wpom.v8i0.7175

Gallos, J. V. (2008). Charting a new course for the scholarship of management teaching and learning: Future directions, powerful opportunities, a hopeful future. Journal of Management Education, 32(5), 535-540. https://doi.org/10.1177/1052562908324357

García-Ramos, C., \& Martínez-Campillo, A. (2017). The service-learning methodology applied to operations management: From the operations plan to business start up. WPOM-Working Papers on Operations Management, 8, 171-176. https://doi.org/10.4995/wpom.v8i0.7200

Gibbs, G., \& Coffey, M. (2000). Training to teach in higher education: A research agenda. Teacher Development, 4(1), 31-44. https://doi.org/10.1080/13664530000200103

Gow, L., \& Kember, D. (1993). Conceptions of teaching and their relationship to student learning. British Journal of Educational Psychology, 63(1), 20-23. https:/ / doi.org/10.1111/j.2044-8279.1993.tb01039.x

Guitart-Tarrés, L., Núñez-Carballosa, A., Jaría Chacón, N., Achcaoucaou, F., Cruz-Cázares, C., Miravitlles, P., \& Huertas García, R. (2017). Playing in operations management. WPOM-Working Papers on Operations Management, 8, 81-85. https://doi.org/10.4995/wpom.v8i0.7171

Kember, D. (1997). A reconceptualisation of the research into university academics' conceptions of teaching. Learning and Instruction, 7(3), 255-275. https://doi.org/10.1016/S0959-4752(96)00028-X

Kember, D., \& Gow, L. (1994). Orientations to teaching and their effect on the quality of student learning. The Journal of Higher Education, 65(1), 58-74. https://doi.org/10.2307/2943877

López-Sánchez, J. I., Fossas-Olalla, M., Rodríguez-Duarte, A., \& Sandulli, F. (2017). A new way to learn. The use of an app (blunder) to manage knowledge with higher education students. WPOM-Working Papers on Operations Management, 8(0), 86-91. https://doi.org/10.4995/wpom.v8i0.7174

Lopez Vargas, C., \& Real, J. C. (2017). Effects of the “jigsaw" technique on student' learning competences within operations management. Revista de métodos cuantitativos para la economía y la empresa, 24, 220-249. 
Maqueira Marín, J. M., Moyano Fuentes, J., \& Bruque Cámara Pedro Nuñez-Cacho Utrilla, S. (2017). Diseño e implementación de una plataforma erp como entorno de aprendizaje en dirección de operaciones design and implementation of an erp platform as practice environment for learning in operations management. Working Papers on Operations Management, 8, 27-31. https://doi.org/10.4995/wpom.v8i0.7112

Marimon, F., \& Berbegal-Mirabent, J. (2017). Sinergias cruzadas entre el aprendizaje de contenidos propios de dirección de operaciones y el uso de herramientas de análisis genéricas cross learning synergies between operation management content and the use of generic analytic tools. Working Papers on Operations Management, 8, 13-14. https://doi.org/10.4995/wpom.v8i0.7015

Marin-Garcia, J. A. (2007). Taller sobre grounded theory y análisis cualitativo de datos con atlas. http://polimedia.upv.es/polimedia.v2/lanza/index.asp?id=ceb62aae-f068-114f-8751-68e5541953ef\&existe400=1

Marin-Garcia, J. A., Maheut, J., \& Garcia-Sabater, J. J. (2017). Comparison of different ways of compute the grades of continuous assessment in the final grade. WPOM-Working Papers on Operations Management, 8(SpIss), 1-12.

Martínez Jurado, P. J., \& Moyano Fuentes, J. (2017). Aprendiendo a enseñar lean management mediante juegos: Revisión sistemática de la literatura learning to teach lean management through games: Systematic literature review. Working Papers on Operations Management, 8, 164-170. https://doi.org/10.4995/wpom.v8i0.7199

Marton, F., Hounsell, D., \& Entwistle, N. (2005). The experience of learning. Implications for teaching and studying in higher education. 3rd (internet) Edition. Edinburgh: University of Edinburgh, Centre for Teaching, Learning and Assessment.

Medina-López, C., Alfalla-Luque, R., \& Marin-Garcia, J. A. (2011). Research in operations management teaching: Trends and challenges. Intangible Capital, 7(2), 507-548. https://doi.org/10.3926/ic.2011.v7n2.p507-548

Mitchell, V. W., \& Harvey, W. S. (in press). How preferable and possible is management research-led teaching impact? Management learning, 0(0), 1350507618770755.

Morente, F., \& Ferràs, X. (2017). Innovation management from the inside: An approach from attention and everyday praxis. Intangible Capital, 13(3), 640-667. https://doi.org/10.3926/ic.1004

Morrell, K., \& Learmonth, M. (2015). Against evidence-based management, for management learning. Academy of Management Learning \& Education, 14(4), 520-533. https://doi.org/10.5465/amle.2014.0346

New, J. R., Clawson, J. G., Coughlan, R. S., \& Hoyle, J. B. (2008). How course portfolios can advance the scholarship and practice of management teaching. Journal of Management Education, 32(1), 8-22.

https://doi.org/10.1177/1052562907309158

Oltra Mestre, M. J., Garcia Palao, C., \& Flor, M. (2017). Análisis de procesos del trabajo en equipo como recurso docente en los cursos de dirección de operaciones teamwork process analysis as a teaching resource in operations management courses. Working Papers on Operations Management, 8, 76-80.

Paricio Royo, J. (2013). ¿repensar la formación del profesorado? ¿porqué habríamos de hacer tal cosa? Revista de Docencia Universitaria, 11(3).

Paricio Royo, J. (2017). Los focos de la investigación en educación superior. Valencia (Spain).

Paricio Royo, J., \& Allueva Pinilla, A. I. (2011). Prácticas y modelos innovadores para la mejora y calidad de la docencia. Prensas Universitarias de Zaragoza.

Pearce, J. L. (2007). We are who we teach - how teaching experienced managers fractures our scholarship. Journal of Management Inquiry, 16(2), 104-110. https://doi.org/10.1177/1056492607302412

Prosser, M., \& Trigwell, K. (1997). Relations between perceptions of the teaching environment and approaches to teaching. British Journal of Educational Psychology, 67(1), 25-35. https://doi.org/10.1111/j.2044-8279.1997.tb01224.x

Ramírez, F. J., \& García-Villaverde, P. M. (2017). Ddi tool: Un juego serio para el desarrollo de las competencias de los estudiantes de grado y postgrado en el entorno de la dirección de operaciones ddi tool: A serious game for the development of competences of graduate and postgraduate students in the operations management environment. Working Papers on Operations Management, 8, 50-53. https://doi.org/10.4995/wpom.v8i0.7127

Ramsden, P. (1992). Learning to Teach in Higher Education. Routledge. 
Rosillo, R., Ángel, J., Dávila, M., Robles, C. F., \& Redondo, M. M. (2017). Sistema de innovación docente aplicado en asignaturas de gestión de empresas teaching innovation system applied in business management subjects. Working Papers on Operations Management, 8, 143-150. https://doi.org/10.4995/wpom.v8i0.7195

Sanchez-Ruiz, L., Blanco, B., \& Marín-García, J. A. (2017). Protocolo: Validación del barómetro incode para medir la competencia de innovación con la teoría de medición de rasch protocol: Validation of the incode barometer to measure the innovation competence through the rasch measurement theory. Working Papers on Operations Management, 8, 120-124. https://doi.org/10.4995/wpom.v8i0.7190

Trigwell, K., Prosser, M., \& Waterhouse, F. (1999). Relations between teachers' approaches to teaching and students' approaches to learning. Higher Education, 37(1), 57-70. https://doi.org/10.1023/A:1003548313194

Vidal-Carreras, P. I., Garcia-Sabater, J. J., \& Canos-Daros, L. (2017). Una propuesta para la disciplina de dirección de operaciones en el grado en ingeniería electrónica industrial y automática a proposal for a course of operations management in the degree in industrial electronic and automatic engineering. Working Papers on Operations Management, 8, 177-180. https://doi.org/10.4995/wpom.v8i0.7205

Vidal, J. V., Martinez, P. C., \& Alfaro, J. A. (2017). Experiences of teaching innovation for the consolidation of a r\&d\&i culture. WPOM-Working Papers on Operations Management, 8, 125-139. https://doi.org/10.4995/wpom.v8i0.7191

Wilson, R. M. S. (2012). Introduction: A continuing discussion on journal quality rankings and their likely impact on accounting education scholarship in the UK. Accounting Education, 21(1), 1-2.

https://doi.org/10.1080/09639284.2012.661168

Journal of Industrial Engineering and Management, 2018 (www.jiem.org)

\section{(ब) (1) (}

Article's contents are provided on an Attribution-Non Commercial 4.0 Creative commons International License. Readers are allowed to copy, distribute and communicate article's contents, provided the author's and Journal of Industrial Engineering and Management's names are included. It must not be used for commercial purposes. To see the complete license contents, please visit https://creativecommons.org/licenses/by-nc/4.0/. 